\title{
Financial Intermediation Development and Total Factor Productivity Growth: Evidence from Chinese Mainland Provincial Panel Data
}

\author{
Yaojun Yao \\ School of Finance, Zhejiang Gongshang University, Hangzhou, China \\ E-mail:yaoyaojun@163.com \\ Received April 27, 2011; revised June 5, 2011; accepted July 1, 2011
}

\begin{abstract}
Modern financial development theories suggest that, financial development can promote technological progress and long-term economic growth. Based on the Chinese mainland provincial panel data, the paper tests empirically the relationship between financial intermediation development and total factor productivity growth. In terms of the degree-of-freedom of bank loan decision-making, the ratio of loans of private enterprises and individuals to total loans is used to measure the development of Chinese financial intermediation. This paper finds that financial intermediation development significantly promotes total factor productivity growth when controlling for other variables, such as capital formation rate, foreign direct investment, government intervention and the urbanization level.
\end{abstract}

Keywords: Financial Intermediation Development, Technological Progress, Total Factor Productivity

\section{Introduction}

Is financial development important to long-term economic growth? Before the emergence of endogenous economic growth theory, a universally recognized answer hadn't been reached. Some pioneering researches pay attention to the relationship between money and growth rather than between finance and growth $[1,2]$. Endogenous economic growth theory provides a good theoretical framework for analyzing the relationship between finance and growth. In this framework, financial development promotes technological progress and exerts positive influence on long-term economic growth [3].

Too many literatures study Chinese finance-growth nexus in China, but few researches focus on the impacts of financial intermediation development on technological progress. Based on the Chinese mainland provincial panel data, this paper tests empirically whether total factor productivity growth, which is used to measure technological progress, has a positive relationship with financial intermediation development. The rest of this paper is organized as follows. Section 2 reviews some literatures. Section 3 discusses the level of Chinese financial intermediation development and the measurement of total factor productivity. Section 4 presents the main em- pirical results. Section 5 concludes the paper.

\section{Literature Review}

In the framework of AK model, financial development improves long-time economic growth through three channels: increasing the marginal productivity of generalized capital, raising saving rate [1,2] and efficiently converting savings to investment [4]. The mechanisms of the first channel include that, financial development will make more finance support available to the efficient projects confronted with liquidity constraints [3], financial markets diversify risk and encourage enterprises to make use of more professional technology [5], and financial intermediations make capital flow into the projects with high social return [6]. Because technical knowledge falls into generalized capital in the models, AK model framework ignores the essential differences between technological progresses (innovation) and capital accumulation. In addition, AK models assume that production activities are always efficient so that technological progress is automatic. Compared with AK models, new Schumpeter models [7] emphasize that technological innovation is the engine of economic growth and believe that technological progress comes from purposeful R \& 
D activities. In the framework of new Schumpeter model, King \& Levine [8] suggest that financial development lowers agency cost (due to the economics of scale), and then promotes technological innovation and economic growth. Their study also indicates that financial system diversifies the risk of innovation activities, which will also improve technological innovation. De la Fuente \& Martin [9] assume that the probability of successful innovation depends on the degree of entrepreneurs' efforts which only can be supervised incompletely with a certain cost. This kind of information friction leads to the emergence of financial intermediaries as agents' supervisors. The contracts between financial intermediaries and entrepreneurs make the entrepreneurs pay optimal level of efforts. With lower supervision costs, the entrepreneurs can get more favorable loan terms to encourage higher-level innovation activities. Blackburn \& Hung [10] have the same conclusion with de la Fuente \& Martin [9], but in their model, the achievements of $\mathrm{R} \& \mathrm{D}$ are assumed to be private information and only enterprises know whether the innovation projects are successful.

Among empirical studies, Beck, et al. [11] find that financial intermediation development significantly promotes total factor productivity (TFP) productivity growth but has a weak link with capital accumulation. However, Rioja \& Valev [12] find that the promotion effect on TFP of the financial intermediation development only exists in developed countries. Tadesse [13] makes use of crosscountry industrial data to find that between the industrial technological progress and the development of bank exists a significantly positive relationship, but the influence of stock markets on industrial technological progress is weak. Inklaar \& Koetter [14] suggest that the relationships between some traditional indicators of financial development and productivity are unsignificant, but the efficiency of financial intermediaries has a significantly positive influence on productivity.

Zhang \& Jin [15] focus on the impacts of Chinese financial intermediation development on technological progress. They find that Chinese financial intermediation development promotes the growth rate of TFP significantly. In the study, the ratio of loan to state-owned enterprises (SOEs) to GDP is used to measure the level of financial deepening. However, the official loans statistics are not categorized by the type of property right of the loanee; therefore, certain estimation methods have to be used to solve problems relating to data acquisition [16], which is likely to lead to unreliable empirical results. Guariglia \& Poncet [17] use the ratio of bank loans to government appropriation in fixed assets investment finance to measure Chinese financial intermediation development, and with this index, they arrive the same conclusion with Zhang \& Jin [15].

\section{Measuring Financial Intermediation Development and TFP}

\subsection{Measuring Financial Intermediation Development}

China's banking sector, in which state-owned banks are dominant, is criticized for inefficient credit allocation [18, 19]. On the one hand, bank loans mostly flow into SOEs, with less than 20 percent being lent to non-SOEs. However, non-SOEs contributed to approximately 65 percent of GDP and 70 - 80 percent of GDP growth in 2007 [20]. On the other hand, although the aim of financial reform in China is to transform the government-controlled banks into independent financial institutions [18], the central government regards credit as an instrument for narrowing the disparities among provincial economies, and provinces with low economic development levels are much more easily able to acquire bank credit [19,21]. Therefore, it is doubtful that loans to GDP can be used as a measure of the development of China's financial intermediation because of inefficient credit distribution. The question now is what index we should choose to measure the true state of Chinese financial intermediation development. In a country with financial repression, the process of financial intermediation deepening could be defined as the results of the system reforms, which include letting banks operate independently for themselves, reducing or even eliminating mandatory loans, and making financial decision-making more marketoriented $[1,2,8]$. In view of this piont, we believe that some structural indicators could be used to measure the development of financial intermediation in China.

To develop a structural indicator to measure the real state of the development of financial intermediation in China, we firstly review the structure of bank loans. In China, bank loans are categorized as short-term, medium-term and long-term loans, trust and entrust loans and other loans, among which short-term loans have the most freedom in terms of decision-making, whereas other loan decisions are subject to many external constraints. For example, according to the official guide for loans, which has been executed since 1998, the amount available for medium-term and long-term loans for fixed assets depends on a set of indices, such as the ratio of medium-term and long-term loans to medium-term and long-term deposits and the ratio of fixed asset loans to total loans. The direction of credit allocation is also required to be consistent with national industrial and macroeconomic policies. There are eight classes of shortterm loans, including: industrial loans, commercial loans, construction industrial loans, agricultural loans, loans to township and village enterprises (TVEs), loans to three 
kinds of foreign-invested enterprises, loans to private enterprises and individuals, and other short-term loans. According to the research conducted by Lin and Li [22], industrial loans, commercial loans and construction industrial loans are designated as loans for SOEs by the government. Agricultural loans are also required by the government to promote the development of agriculture, rural areas and farmers. Loans for TVEs are influenced by local governments with strong motivation to stimulate local economic growth under the background of fiscal decentralization. In addition, three kinds of foreign-invested enterprises have enjoyed much supernational treatment, and banks are often pressed to provide loans to them. Banks are more independent in the decisionmaking relating to loans to private enterprises and individuals. The increase in the ratio of loans for private enterprises and individuals to total loans reflects the enhancement of the degree-of-freedom of banks making loan decisions. Therefore, we argue that it is reasonable to measure the development of financial intermediation in China using the ratio of loans of private enterprises and individuals to total loans. This index has positive correlation with economic growth; see Figure 1, which is consistent with the prediction of the mainstream theory of financial development.

\subsection{Measuring TFP}

We suppose that the form of production function is Cobb-Douglas form:

$$
Y=K^{a}(A H)^{1-a}
$$

where $y$ is output, $k$ is physical capital, $A$ is technology level, $H$ is human capital, and $\alpha$ is the output elasticity of capital. Suppose that the relationship between $H$ and the number of labor force $L$ is

$$
H=e^{\varphi(E)} L
$$

where $E$ is per capita education years of labor force, and $\varphi(E)$ is the weighed sum of the return rates of education. According to Psacharopoulos \& Patrinos [23], in China the return rate of education at the stage of primary education is 0.18 , at the stage of secondary education is 0.134 and at the stage of higher education is 0.151 . For example, if $E$ is 14 , then

$\varphi(E)=6 \times 0.180+6 \times 0.134+2 \times 0.151=2.186$.

By (1) and (2), we have

$$
A^{1-a}=\frac{Y}{K^{a} H^{1-a}}=\frac{Y}{K^{a}\left(e^{\varphi(E)} L\right)^{1-a}}
$$

According to $\mathrm{Fu} \& \mathrm{Wu}$ [24], $A^{1-a}$ is TFP. By the data sources that are showed in Section 4, we can calculate out the values of TFP that are presented in Table 1.

\section{Empirical Analysis}

\subsection{The Econometric Model and Variables}

The econometric model in this paper is:

$$
f p_{i t}=a_{i}+\beta \text { find }_{i t}+\sum \gamma_{j} \text { Control }_{j i t}+\varepsilon_{i t}
$$

where $t f p$ is the growth rate of TFP; find is the level of financial intermediation development, which is measured with the ratio of loans of private enterprises and individuals to total loans; Control represents other control variables; $a$ is time-constant provincial effects; $\varepsilon$ is the idiosyncratic error; $\beta$ and $\gamma$ represent the coefficients to be estimated; The subscripts $i$ and $t$ represent the provinces and time, respectively; $j$ indicates other control variables. Following Zhang \& Jin [15], other control variables include capital formation rate (inv), foreign direct investment ( $f d i)$ which is measured by the ratio of actually utilized foreign direct investment to

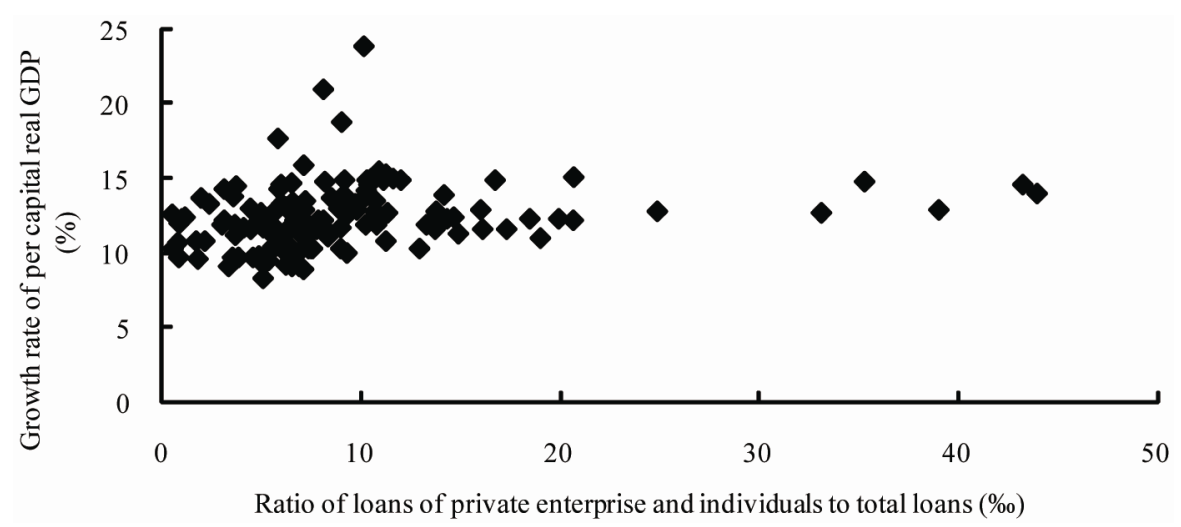

Figure 1. Ratio of loans of private enterprises and individuals to total loans and the growth rate of per capita real GDP in each province, 2002-2006. Sources: Drawn by the author according to Financial statistics and analysis for each year and Statistical yearbook for each province. 
Table 1. Chinese mainland provincial TFP (2001-2005).

\begin{tabular}{|c|c|c|c|c|c|}
\hline & 2001 & 2002 & 2003 & 2004 & 2005 \\
\hline Beijing & 0.438 & 0.404 & 0.402 & 0.413 & 0.418 \\
\hline Tianjin & 0.454 & 0.480 & 0.498 & 0.522 & 0.553 \\
\hline Hebei & 0.251 & 0.259 & 0.267 & 0.280 & 0.298 \\
\hline Shanxi & 0.231 & 0.241 & 0.250 & 0.264 & 0.272 \\
\hline Inner Mongolia & 0.244 & 0.256 & 0.274 & 0.282 & 0.303 \\
\hline Liaoning & 0.441 & 0.480 & 0.507 & 0.548 & 0.523 \\
\hline Jilin & 0.249 & 0.243 & 0.251 & 0.244 & 0.275 \\
\hline Heilongjiang & 0.311 & 0.325 & 0.34 & 0.358 & 0.378 \\
\hline Shanghai & 0.704 & 0.710 & 0.718 & 0.749 & 0.763 \\
\hline Jiangsu & 0.435 & 0.465 & 0.479 & 0.499 & 0.504 \\
\hline Zhejiang & 0.353 & 0.361 & 0.365 & 0.368 & 0.384 \\
\hline Anhui & 0.231 & 0.241 & 0.239 & 0.255 & 0.280 \\
\hline Fujian & 0.307 & 0.319 & 0.328 & 0.34 & 0.349 \\
\hline Jiangxi & 0.238 & 0.247 & 0.243 & 0.257 & 0.276 \\
\hline Shandong & 0.292 & 0.296 & 0.313 & 0.327 & 0.343 \\
\hline Henan & 0.159 & 0.164 & 0.174 & 0.182 & 0.196 \\
\hline Hubei & 0.290 & 0.305 & 0.302 & 0.313 & 0.333 \\
\hline Hunan & 0.189 & 0.195 & 0.201 & 0.210 & 0.225 \\
\hline Guangdong & 0.397 & 0.419 & 0.444 & 0.461 & 0.461 \\
\hline Guangxi & 0.128 & 0.134 & 0.139 & 0.144 & 0.156 \\
\hline Sichuan & 0.265 & 0.278 & 0.281 & 0.300 & 0.322 \\
\hline Guizhou & 0.125 & 0.128 & 0.124 & 0.129 & 0.140 \\
\hline Yunnan & 0.283 & 0.310 & 0.293 & 0.292 & 0.307 \\
\hline Shaixi & 0.200 & 0.210 & 0.197 & 0.209 & 0.242 \\
\hline Gansu & 0.288 & 0.290 & 0.283 & 0.291 & 0.331 \\
\hline Qinghai & 0.159 & 0.157 & 0.170 & 0.176 & 0.201 \\
\hline Ningxia & 0.175 & 0.173 & 0.188 & 0.187 & 0.212 \\
\hline Xinjiang & 0.209 & 0.214 & 0.207 & 0.213 & 0.242 \\
\hline
\end{tabular}

Sources: Calculate by the author according to the data sources that are showed in Section 4.

nominal GDP), government intervention (gov, which is measured by the local fiscal expenditures net of the expenditures for culture, education, science and health), the urbanization level (town, which is measured by the proportion of non-agricultural population in the total population).

$t f p$ is calculated by Equation (3), where the data for $y$ and $L$ are available from Chinese statistical yearbook; the data for physical capital (at the price of 1952) are obtained by the method of Zhang, et al. [25]; the data for per capita education years are obtained by the method of Tian [26]. Following Tian [26], the output elasticity of capital $\alpha$ is 0.483 . find is calculated by the data from Financial statistics and analysis. The data for other control variables are available from Chinese statistical yearbook. The data for loans of private enterprises and individuals in most provinces are published from 2002, and also in order to isolate the effect of the global financial crisis, so the empirical study uses the Chinese mainland provincial panel data in years 2002-2005. Tibet Autonomous Region is not included in the samples for the difficulties in data extraction. In addition, Hainan and Chongqing are included in Guangdong and Sichuan. The descriptive statistics of the indexes are presented in Table 2.

\subsection{Results of Estimation and Discussion}

Because the samples are not selected randomly, this paper uses fixed effect method rather than random effect method to estimate the model. The results of the fullsample estimation are presented in column 2 of Table 3.

If the idiosyncratic error doesn't meet the standard assumption, the common standard error is always bias and so the inferences of significance of estimated coefficients are incorrect. Wooldridge test [27] suggests that we can't reject the null hypothesis that the within-group error terms are first-order serially uncorrelated even at the $10 \%$ significance level; the result of Pesaran test suggests that the null hypothesis that the between-group error terms are uncorrelated is rejected at the 5\% significance level; Adjusted Wald test provides the powerful evidence for the groupwise heteroskedasticity of error terms. With these test results, we decide to deduce significance of each coefficient under cluster-robust standard error.

According to full-sample estimation, we find that financial intermediation development has a positive effect on TFP growth at the $5 \%$ significance level, which is consistent with the prediction of the mainstream theory of financial development. The coefficient of capital formation rate (inv) is negative and significant at the $10 \%$ significance level, which indicates that the increase of investment-to-GDP ratio continually will prevent the improvement of Chinese economic growth efficiency. The sign of foreign direct investment ( $f d i)$ is negative and significant at the $10 \%$ significance level. A potential explanation for the result is that, the inflow of foreign capital slows the process of domestic R \& D and innova

Table 2. Descriptive statistics of variables.

\begin{tabular}{cccccc}
\hline Variables (unit) & Observations & Mean & $\begin{array}{c}\text { Standard } \\
\text { deviation }\end{array}$ & Minimum Maximum \\
\hline tfp (\%) & 112 & 3.967 & 4.118 & -7.763 & 15.789 \\
find (\%) & 112 & 8.721 & 6.717 & 0.885 & 43.209 \\
inv & 112 & 0.492 & 0.109 & 0.309 & 0.849 \\
fdi (US \$/RMB) & 112 & 0.487 & 0.469 & 0.103 & 2.581 \\
gov & 112 & 0.120 & 0.047 & 0.059 & 0.294 \\
town & 112 & 0.325 & 0.127 & 0.149 & 0.646 \\
\hline
\end{tabular}


Table 3. Results of estimation.

\begin{tabular}{ccc}
\hline & Full-sample estimation & Partial-sample estimation \\
\hline \multirow{3}{*}{ find } & $0.2403^{* *}$ & $0.2271^{* *}$ \\
& $(0.2152)$ & $(0.2553)$ \\
inv & {$[0.1161]$} & {$[0.1211]$} \\
& $-23.3540^{*}$ & $-36.6899^{* *}$ \\
& $(13.9601)$ & $(16.6429)$ \\
fdi & {$[13.1491]$} & {$[16.5993]$} \\
& $-4.4952^{*}$ & $-14.9033^{* *}$ \\
gov & $(3.0697)$ & $(6.2348)$ \\
& {$[2.4164]$} & {$[7.0309]$} \\
& -35.2687 & -7.2685 \\
town & $(53.0785)$ & $(56.8894)$ \\
& {$[51.4383]$} & {$[60.2504]$} \\
interception & 34.5628 & 10.5967 \\
& $(26.8882)$ & $(30.5926)$ \\
& {$[25.5632]$} & {$[23.2099]$} \\
Wooldridge test & 8.5348 & $25.1383^{*}$ \\
& $(13.8613)$ & $(15.8655)$ \\
Pesaran test & {$[13.4438]$} & {$[13.1622]$} \\
& $\mathrm{F}(1,27)=0.441$ & $\mathrm{~F}(1,24)=0.031$ \\
Adjusted Wald test & Prob $=0.512$ & Prob $=0.863$ \\
& $\mathrm{CD}=1.781$ & $\mathrm{CD}=2.416$ \\
& Prob $=0.075$ & Prob $=0.016$ \\
& $\chi^{2}(28)=11814.16$ & $\chi^{2}(25)=14889.48$ \\
& Prob $=0.000$ & Prob $=0.000$ \\
\hline
\end{tabular}

Notes: ${ }^{*},{ }^{* *}$ and ${ }^{* * *}$ indicate significance at the 10,5 and 1 percent levels, respectively. Figures in parentheses are common standard errors while those in square brackets are cluster-robust standard error. The deductions of significance of each coefficient go under cluster-robust standard error.

tion development and leads to high technological dependence, and as a result, the policy to promote domestic industrial technological progress through the introduction of foreign capital hasn't achieved great accomplishments. The sign of government intervention (gov) is negative, which is consistent with the theoretical expectations, but not significant. This paper doesn't find that urbanization can promote TFP growth. According to Zhang \& Jin [15], if without sustainable economies of scale, urbanization has a weak impact on TFP growth, even though highlevel urbanization might promote the initial level of productivity.

In empirical studies the robustness of statistical inference is a noteworthy problem. Tusi [28] finds that, when studying China's economic growth, whether the sample includes Beijing, Tianjin and Shanghai or not might lead to very different empirical conclusions. Boyreau-Debray [29] points out that it is debatable whether the above three municipalities should be included when studying the relationship between China's economic growth and finance development, because there is always a high degree of capital mobility between these municipalities and the surrounding provinces. Therefore, to verify the ro- bustness of estimation results, we re-estimate the model with a sample excluding the above three municipalities (see column 3 of Table 3). The results of partial-sample estimation still indicate that the positive relationship between financial intermediation development and economic growth is robust.

\section{Conclusions and Policy Implications}

For policy-making to fuel economic growth, it is very important that the mechanism through which financial development promotes economic growth is identified [30]. By new Schumpeter models in endogenous economic growth theory, financial development can promote technological progress and long-term economic growth. Using Chinese mainland provincial panel data, this paper examines the relationship between financial intermediation development and TFP growth. In terms of the degree-of-freedom of bank loan decision-making, the ratio of loans of private enterprises and individuals to total loans is used to measure the development of Chinese financial intermediation. When controlling for other variables, such as capital formation rate, foreign direct investment, government intervention and the urbanization level, this paper finds that financial intermediation development significantly promotes TFP growth, regardless of whether the sample includes Beijing, Tianjin and Shanghai.

The empirical results in the present paper also provide some interesting policy implications for China's economic growth and financial development. The financial intermediation development has had a positive and statistically significant effect on TFP growth, suggesting that a sound financial sector is indispensable for economic growth. To reach a higher stage of financial development, it is most important and urgent that allocative efficiency of financial resources be improved. Taking this into consideration, financial system reforms, including encouraging banks to operate independently, reducing or eliminating mandatory loans and making financial decision-making more market-oriented, should be further pursued.

\section{Acknowledgements}

The project is supported by Zhejiang Provincial Natural Science Foundation of China (No. Y7100670) and Key Research Basement of Humanities of Social Sciences (Finance) of Zhejiang Provincial Higher Education Institutions.

\section{References}

[1] R. I. McKinnon, "Money and Capital in Economic De- 
velopment,” The Brookings Institution, Washington, DC, 1973.

[2] E. S. Shaw, "Financial Deepening in Economic Development,” Oxford University Press, New York, 1973.

[3] R. Levine, "Financial Development and Economic Growth: Views and Agenda," Journal of Economic Literature, Vol. 35, No. 2, 1997, pp. 688-726.

[4] M. Pagano, "Financial Markets and Growth: An Overview,” European Economic Review, Vol. 37, No. 2-3, 1993, pp. 613-22. doi:10.1016/0014-2921(93)90051-B

[5] G. Saint-Paul, "Technological Choice, Financial Markets and Economic Development," European Economic Review, Vol. 36, No. 4, 1992, pp. 763-781. doi:10.1016/0014-2921(92)90056-3

[6] J. Greenwood and J. Boyan, "Financial Development, Growth, and the Distribution of Income," Journal of Political Economy, Vol. 98, No. 5, 1990, pp. 1076-1107. doi:10.1086/261720

[7] P. Aghion and H. Peter, "Endogenous Growth Theory," MIT Press, Cambridge, 1998.

[8] R. G. King and R. Levine, "Finance and Growth: Schumpeter Might Be Right," Quarterly Journal of Economics, Vol. 108, No. 3, 1993, pp. 717-737. doi: $10.2307 / 2118406$

[9] A. De la Fuente and M. M. José, "Innovation, Bank Monitoring and Endogenous Financial Development”, Journal of Monetary Economics, Vol. 38, No. 2, 1996, pp. 269-301. doi:10.1016/S0304-3932(96)01277-9

[10] K. Blackburn and V. T. Y. Hung, "A Theory of Growth, Financial Development and Trade,” Economica, Vol. 65, No. 257, 1998, pp. 107-124 doi:10.1111/1468-0335.00116

[11] B. Thorsten, R. Levine and N. Loayza, "Finance and Sources of Growth," Journal of Financial Economics, Vol. 58, No. 1-2, 2000, pp. 261-310. doi:10.1016/S0304-405X(00)00072-6

[12] F. Rioja and N. Valev, "Finance and the Sources of Growth at Various Stages of Economic Development," Economic Inquiry, Vol. 42, No. 1, 2004, pp. 27-40. doi:10.1093/ei/cbh049

[13] S. Tadesse, "Financial Development and Technology," Working Paper No. 879, William Davidson Institute, University of Michigan, Ann Arbor, 1997,

[14] R. Inklaar and K. Michael, "Financial Dependence and Industry Growth in Europe: Better Banks and Higher Productivity," Working Paper No. 100, Groningen Growth and Development Centre, University of Groningen, Groningen, 2008.

[15] J. Zhang and J. Yu, “Analysis on Relationship of Deepening Financial Intermediation and Economic Growth in China," Economic Research Journal, Vol. 40, No. 11, 2005, pp. 34-45.

[16] J. Aziz and D. Christoph, "Growth-Financial Intermedia- tion Nexus in China,” IMF Working Paper No. 02/194, International Monetary Fund, Washington, DC, 2002.

[17] A. Guariglia, and P. Sandra, "Could Financial Distortions Be No Impediment to Economic Growth after All? Evidence from China," Working Paper No. 06/36, Leverhulme Centre for Research on Globalization and Economic Policy, Nottingham, 2006,

[18] N. R. Lardy, "China’s Unfinished Economic Revolution,” Brookings Institution Press, Washington, DC, 1998.

[19] A. Park and S. Kaja, “Tests of Financial Intermediation and Banking Reform in China,” Journal of Comparative Economics, Vol. 29, No. 4, 2001, pp. 608-644. doi:10.1006/jcec.2001.1740

[20] J. L. Du, L. Yi and Z. G. Tao, "Bank Loans and Trade Credit under China's Financial Repression,” The China International Conference in Finance, Guangzhou, 7-10 July 2009.

[21] H. Chen, "Development of Financial Intermediation and Economic Growth: The Chinese Experience,” China Economic Review, Vol. 17, No. 4, 2006, pp. 347-362. doi:10.1016/j.chieco.2006.01.001

[22] Y. F. Lin and Z. Y. Li, "The Reform of State-Owned Enterprises and Financial Systems in China," CCER Discussion Paper No. C2003027, Chinese Center of Economic Research, Peking University, Beijing, 2003.

[23] G. Psacharopoulos and H. A. Patrinos, "Returns to Investment in Education: A Further Update," Education Economics, Vol. 12, No. 2, 2004, pp. 111-134. doi:10.1080/0964529042000239140

[24] X. X. Fu and L. X. Wu, "The Contributions of Total Factor Productivity to Chinese Regional Differences,” World Economy, Vol. 51, No. 9, 2006, pp. 12-22.

[25] J. Zhang, G. Y. Wu and J. P. Zhang, "The Estimation of Chinese Provincial Physical Capital: 1952-2000,” Economic Research Journal, Vol. 32, No. 10, 2004, pp. 3544.

[26] M. Tian, "Chinese Regional Income Gaps from the View of Total Factor Productivity,” Master's Thesis, Tianjin University of Finance and Economics, Tianjin, 2007.

[27] D. M. Drukker, "Testing for Serial Correlation in Linear Panel-Data Models,” The Stata Journal, Vol. 3, No. 2, 2003, pp. 168-177.

[28] K.-Y. Tusi, "Economic Reform and Interprovincial Inequalities,” Journal of Development Economics, Vol. 50, No. 2, 1996, pp. 353-368. doi:10.1016/S0304-3878(96)00406-3

[29] G. Boyreau-Debray, "Financial Intermediation and Growth: Chinese Style," Policy Research Working Paper No. 3027, World Bank, Washington, DC, 2003.

[30] R. Levine, N. Loayza and T. Beck, "Financial Intermediation and Growth: Causality and Causes," Journal of Monetary Economics, Vol. 46, No. 1, 2000, pp. 31-77. doi:10.1016/S0304-3932(00)00017-9 